\title{
TURKISH DRIFTNET FISHERY FOR ALBACORE, THUNNUS ALALUNGA (ACTINOPTERYGII: PERCIFORMES: SCOMBRIDAE), AND INCIDENTAL CATCHES IN THE EASTERN MEDITERRANEAN
}

\author{
Okan AKYOL ${ }^{*}$ and Tevfik CEYHAN \\ Ege University, Faculty of Fisheries, 35440 Urla, Izmir, Turkey
}

\begin{abstract}
Akyol O., Ceyhan T. 2012. Turkish driftnet fishery for albacore, Thunnus alalunga (Actinopterygii: Perciformes: Scombridae), and incidental catches in the eastern Mediterranean. Acta Ichthyol. Piscat. 42 (2): 131-135.
\end{abstract}

Background. Fishing operations for albacore, Thunnus alalunga (Bonnaterre, 1788), are mainly carried out by pelagic longline in the Mediterranean, whereas driftnets are the main fishing gear for albacore catch in Turkey. The albacore driftnet fishery has been carried out since 2004 and about 40 vessels participated in this venture between May and July especially in the Gulf of Antalya. The aim of this study was to determine the Catch Per Unit of Effort (CPUE) and bycatch from the Turkish albacore fleet during the 2010-2011 fishing seasons.

Materials and methods. This study was carried out with 18 representative drift-netters based at the port of Alanya, Kaş, Fethiye, and Sı ğacık from May to July 2010 and from May to July 2011. On each fishing trip, data were collected on date, location, depth, fishing boat characteristics, fishing gear aspects, and the capture of both target and non-target species by weight (biomass) and number.

Results. A total of 125 data sets were collected. The mean CPUEs for albacore by number and weight were 13 \pm 1.6 specimens and $90 \pm 11 \mathrm{~kg}$ per $\mathrm{km}$ of net, respectively. A total of 12 species, belonging to 9 families were caught during the sampling period. The target species - albacore — had the highest ratio both in number $(76.6 \%)$ and weight (62.8\%) followed by, Euthynnus alletteratus, Xiphias gladius, Thunnus thynnus, and Auxis rochei. Ratios of biomass and number ratios of the non-target species to the target albacore were $1: 0.59 \mathrm{~kg}$ and $1: 0.31$ individuals, respectively.

Conclusion. Traditional Turkish pelagic driftnet fishery, dating back to the early 1900s, was halted in July 2011 by the Turkish fisheries authority to comply with the international ban. The Turkish fisheries authority strongly supports the transition towards the usage of pelagic longlines as recommended by ICCAT and should supply technical support to the fishermen.

Keywords: albacore, Thunnus alalunga, driftnet fishery, incidental catch, CPUE, eastern Mediterranean

\section{INTRODUCTION}

Albacore, Thunnus alalunga (Bonnaterre, 1788), is a highly migratory epipelagic oceanic species, found mainly in midwater to depths of $100 \mathrm{~m}$, which has a cosmopolitan distribution in all tropical and temperate oceans. As the albacore is a globally important target species, it accounts for close to $200000 \mathrm{t}$ annually (Golani et al. 2006).

The GFCM-ICCAT Expert Consultation Meeting in Bari in 1990 indicated that albacore in the Mediterranean should be considered as a separate stock. Moreover, genetic analyses are currently being carried out to confirm or refute the existence of a separate Mediterranean stock (Anonymous 1995).

Driftnet, longline, hand line, and troll are the main gears used and albacore are also occasionally caught by French purse-seiners, by the Spanish coastal artisanal fleet, and by the sport fishery (Anonymous 1995).
The driftnet fishery for albacore tuna in the north-east Atlantic developed in the late 1980s, and France introduced the use of driftnets in this fishery in 1986, followed by Ireland in 1990 and the UK in 1991 (Ross and Isaac 2004). Although various countries (including France, Ireland, Portugal, and the UK in the Atlantic, Spain in Gibraltar and Italy in the Mediterranean, and in minimal extent France) were fishing with albacore driftnets until the mid1990's (Anonymous 1995), the driftnet fishery has been abandoned in all these countries since then. However, Oceana and MarViva (Cornax and Pardo 2009) identified 93 illegal driftnetters in Italy and the main ports used for this fishing in Morocco during 2008.

In the early 2000s, the European Union and the International Commission for the Conservation of Atlantic Tunas (ICCAT) enforced a recommendation prohibiting the use of driftnets in the Mediterranean follow-

\footnotetext{
* Correspondence: Dr Okan Akyol, Ege Üniversitesi, Su Ürünleri Fakültesi, 35440 Urla, İzmir, Turkey, phone: +90 2327521162 (133), fax: +90 232 3747450 , e-mail: okan.akyol@ege.edu.tr.
} 
ing a UN resolution. In 2006, drift-netting in Turkey was also officially prohibited (Anonymous 2006). As a result, drift-netting has currently been tended to decrease due to the banning since 2006. However, the majority of fishermen have made some modifications in their nets and put some weights and buoys on both sides of the nets in order to get out of scope of conventional drift net definition in Notification 2/1 Regulating Commercial Fishing (Akyol and Ceyhan 2011). Thus, the Turkish fisheries authorities have given a limited permission for traditional pelagic driftnet fishery in Turkish seas until the July 2011. Finally, this fleet stopped its activity in July 2011 in order to compliance with UN and EU binding resolutions.

In Turkey, the annual yield of albacore has been fluctuated between 27 and $852 \mathrm{t}$ since 2004, and the last statistics shown that the catch amount was $402 \mathrm{t}$ in 2010 (Anonymous 2011). Albacore driftnet fishery has been carried out since 2004 and about 40 vessels participated in this fishery between May and July especially in the Gulf of Antalya. Ceyhan et al. (2011) reported that the albacore driftnet was made of 23 tex/21 No. rope thickness, multifilament polyamide (PA) material; $170 \mathrm{~mm}$ stretched mesh size and varied from 300 to 600 mesh deepness.

There are only three albacore driftnet studies on albacore in Turkish seas. Karakulak et al. (2007) shortly presented the albacore driftnet fishery in Gulf of Antalya for the first time and recently, Ceyhan et al. (2011) reported the albacore fishery, detailed on fishing ports, fishing fleet, fishing grounds and period, technical characteristics of the driftnets, and fish length frequency. Lastly, Akyol and Ceyhan (2012) studied the moon phase's influence on CPUE of Turkish albacore driftnet fishery.

The aim of this study was to determine the catch per unit effort (CPUE) and incidental catch ratios from Turkish albacore fleet during the 2010-2011 fishing seasons.

\section{MATERIALS AND METHODS}

We monitored randomly the daily fishing activity of 18 representative drift-netters based at the ports of Alanya, Kaş, Fethiye, and Sığacık (Fig. 1) within two seasons: from May to July 2010 and from May to July 2011. A total of 125 surveying operations (scientists onboard and in harbour surveys and reports from fishermen's logbooks) were carried out, including 49 in Alanya, 5 in Kaş, 13 in Fethiye on the Turkish Mediterranean coasts (TM), and 58 in Siğacık areas on the Turkish Aegean coasts (TA). On each fishing trip, data were based on: (1) date, location, and depth; (2) fishing boat characteristics such as overall length, gross tonnage, and propelling engine power; (3) fishing gear aspects such as mesh size, total length of the net; and (4) the capture of both target- and non-target species by weight and number.

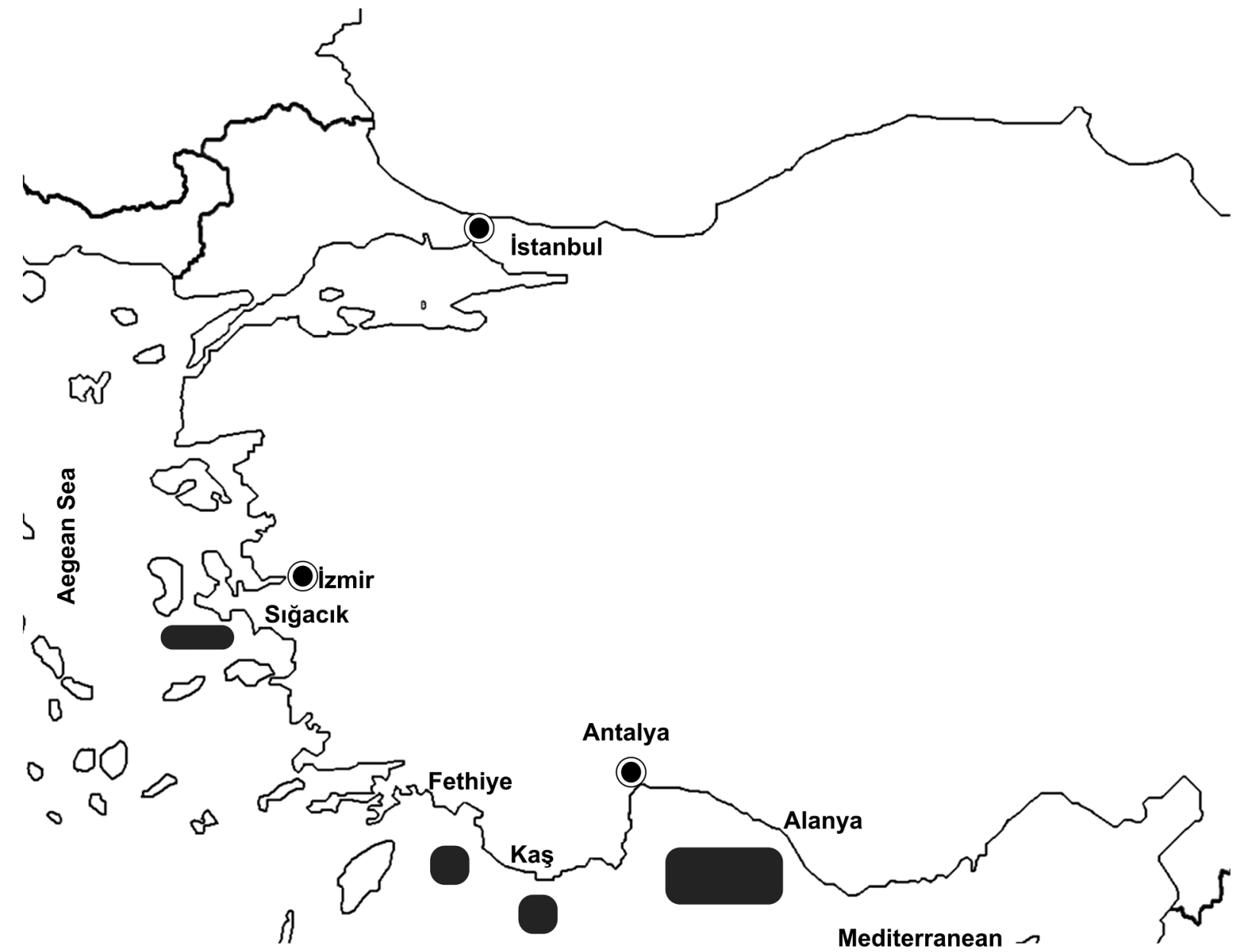

Fig. 1. Sampling areas of Turkish driftnet fishery targeting albacore, Thunnus alalunga 
Modifying formulas from De Metrio and Megalafonou (1988) we propose formulas to describe two parameters important for this study:

Fishing effort $(F)$ :

$$
F=D \times L \times 1000^{-1}
$$

where: $D$ is the number of fishing days and $L$ represents the mean length of the net placed daily in the sea (divided by the $1000 \mathrm{~m}$ net unit); and the Catch Per Unit of Effort (CPUE), in relation to the fish number per $\mathrm{km}$ of the net: $\mathrm{CPUE}_{N}=N \times F^{-1}$

where: $N$ in the fish number; and the Catch Per Unit of Effort (CPUE), in relation to the fish biomass per $\mathrm{km}$ of the net:

$$
\mathrm{CPUE}_{B}=B \times F^{-1}
$$

where: $B$ is the fish biomass

Estimates of incidental catches were made from the bycatches, and retained portion of target catches at the species level.

To test for normality and homoscedacity, each dataset was evaluated using tests of: Kolmogorov-Smirnov (Zar 1999) and Bartlett (Bartlett 1937a, b). If the datasets passed the normality test, parametric procedures were employed; otherwise, data were transformed using an appropriate transformation process (e.g., log) to meet the underlying assumptions of normality (Zar 1999). Comparisons of differences between target and non-target fish according to weight $(\mathrm{kg})$ by fishing areas were tested by Student's $t$-tests on log-transformed data. Differences among means CPUEs by number and biomass of albacore were tested using Student's $t$-tests. All of the means were given with standard error $( \pm \mathrm{SE})$.

\section{RESULTS}

The Turkish albacore driftnet fishery is carried out in some areas, especially off Alanya, Kaş, Fethiye, TM coasts (depth range: 800-2500 m), and off Siğacık Bay, TA coasts (depth range: 150-400 m).

A total of 125 data sets were recorded during the observed fishing operations, but albacore catch was only obtained from 84 surveying operations. Total length of all surveyed driftnets reached $446 \mathrm{~km}$, individual nets ranged from 2000 to $7200 \mathrm{~m}$ with an average of $5310 \pm 129 \mathrm{~m}$. The mean CPUEs for albacore by number and weight were calculated as $13 \pm 1.6$ specimens and $90 \pm 11 \mathrm{~kg}$ per $\mathrm{km}$ net, respectively (Table 1 ). There were no significant differences among means of CPUEs in either number or biomass of albacore $(P>0.05)$.

A total of 12 species, belonging to nine families of fish, dolphins, and turtles (7859 specimens; $66069 \mathrm{~kg}$ ), including four Scombridae, one Coryphaenidae, one Istiophoridae, one Lamnidae, one Alopiidae, one Centrolophidae, one Xiphiidae, one Delphinidae, and one Cheloniidae were caught. The target species, albacore had the highest ratio both in number $(76.6 \%)$ and weight (62.8\%) followed by little tunny, Euthynnus alletteratus (Rafinesque, 1810); swordfish, Xiphias gladius L.; Atlantic bluefin tuna, Thunnus thynnus (L.); and bullet tuna, Auxis rochei (Risso, 1810). Biomass and number ratios of the non-target species to the target albacore were $1: 0.59 \mathrm{~kg}$ and $1: 0.31$ specimens, respectively (Table 2).

Figure 2 shows the distribution of the most abundant target and non-target species according to percentages of catch biomass $(\mathrm{kg})$ in both fishing areas. The biomass ratio of the target species, albacore, was much higher $(97.4 \%)$ on the TM coast than the TA coastal area $(2.6 \%)$, while swordfish had the highest ratio $(76.7 \%)$ in the TA area. E. alletteratus was captured with high proportion $(66.8 \%)$ in the TM, while T. thynnus was higher $(72 \%)$ in the TA. Depending on the fishing areas, T. alalunga biomass differed significantly $(t=8.870 P<0.05), X$. gladius biomass $(t=2.540, P<0.05)$, and the biomass of other fishes $(t=3.131, P<0.05)$ also differed significantly, while no significant differences were identified between E. alletteratus biomass $(t=1.729, P>0.05)$, and $T$. thynnus biomass $(t=1.874, P>0.05)$ across areas.

\section{DISCUSSION}

The albacore driftnet fleet has 40 vessels, and they preferably fish on moonless nights between May and July. In terms of moon phases, Akyol and Ceyhan (2012) showed that the mean CPUE of albacore was higher in the dark period than the light period.

The average overall length (LOA), gross tonnage (GT), propelling engine power (KW), and number of crew of the sampled albacore drift-netters $(n=18)$ ranged from 10.5 to $34 \mathrm{~m}$ (average: $16.8 \pm 1.5$ ); from 7 to $148 \mathrm{GT}$ (average: $41.7 \pm 10.5$ ); from 25 to $1306 \mathrm{KW}$ (average: $273 \pm 67 \mathrm{KW}$ ); and from 2 to 10 persons (average: $5.2 \pm 0.5$ ), respectively. Karakulak et al. (2007) reported that the albacore fishery was performed by 18 vessels, ranging from 14 to $25 \mathrm{~m}$ LOA and 149 to $373 \mathrm{KW}$ engine powers in the 2006 season. The comparison between Karakulak et al. (2007) and our results suggest that the fishing vessels in terms of LOA and machine powers have expanded in the last few years.

Table 1

Fishing effort and Catch Per Unit of Effort in gillnet fishery for albacore, Thunnus alalunga, related to the number or to the biomass, based on 84 surveying operations in the eastern Mediterranean

\begin{tabular}{lcccccc}
\hline & \multicolumn{2}{c}{ Length of net $[\mathrm{m}]$ Albacore number } & Albacore biomass & Fishing effort $(F)$ & CPUE $_{N}$ & CPUE $_{B}$ \\
\hline Minimum & 2000 & 1 & 7 & 2 & 0.3 & 2.2 \\
Maximum & 7200 & 715 & 5000 & 7.2 & 99.3 & 694.4 \\
Mean \pm SE & $5310 \pm 129$ & $73 \pm 11$ & $500 \pm 74$ & $5.3 \pm 0.1$ & $13 \pm 1.6$ & $90 \pm 11$ \\
\hline
\end{tabular}

$F=D \times L \times 1000^{-1}$; where: $D$ is the number of fishing days and $L$ represents the mean length of the net placed daily in the sea (divided by the $1000 \mathrm{~m}$ net unit); $\mathrm{CPUE}_{N}=$ Catch Per Unit of Effort (number); $\mathrm{CPUE}_{B}=$ Catch Per Unit of Effort (biomass); $\mathrm{SE}=$ standard error. 
Table 2 In this study, the mean albacore $\mathrm{CPUE}_{N}$ was $13 \pm 1.6$

Total catch of albacore, Thunnus alalunga, and non-target species and their ratios by number and biomass during 125 surveying operations in the eastern Mediterranean

\begin{tabular}{lrrrr}
\hline \multirow{2}{*}{ Species } & \multicolumn{2}{c}{ Number } & \multicolumn{2}{c}{ Biomass } \\
\cline { 2 - 5 } & \multicolumn{1}{c}{ N } & \multicolumn{1}{c}{$\mathrm{kg}$} & \multicolumn{1}{c}{$\%$} \\
\hline Alopias vulpinus & 2 & 0.03 & 320 & 0.48 \\
Auxis rochei & 130 & 1.65 & 157 & 0.24 \\
Caretta caretta & 5 & 0.06 & 254 & 0.38 \\
Centrolophus niger & 1 & 0.01 & 3 & 0.005 \\
Coryphaena hippurus & 10 & 0.13 & 106 & 0.16 \\
Euthynnus alletteratus & 1292 & 16.45 & 8433 & 12.76 \\
Isurus oxyrinchus & 1 & 0.01 & 50 & 0.08 \\
Stenella coeruleoalba & 7 & 0.09 & 450 & 0.68 \\
Tetrapturus belone & 5 & 0.06 & 119 & 0.18 \\
Thunnus alalunga & 6016 & 76.55 & 41470 & 62.77 \\
Thunnus thynnus & 93 & 1.18 & 2373 & 3.59 \\
Xiphias gladius & 297 & 3.78 & 12334 & 18.67 \\
\hline Total & 7859 & 100.0 & 66069 & 100.0 \\
Albacore : non-target & $1: 0.31$ & & $1: 0.59$ & \\
fish & & &
\end{tabular}

Sığacık Bay as a new fishing area for both albacore and swordfish has been used for the last five years.

In the presently reported study, the albacore comprised $\sim 77 \%$ of the total observed catch (by number). Rogan and Mackey (2007) calculated that the albacore catch ratio was $89.6 \%$ for the Irish fleet in the NE Atlantic in two years of surveys, 1996 and 1998. Observed target catch ratios of albacore show that this fishery is more effective in terms of target fish.

Additionally, the biomass ratio of albacore in the TM region was much higher $(97.4 \%)$ than those of the TA fishing area $(2.6 \%)$, while swordfish had the highest ratio $(76.7 \%)$ in the TA. This difference suggests that the fleet targeted swordfish by using albacore driftnets off Siğacık Bay on the return trip. pecimens, while $\mathrm{CPUE}_{B}$ was $90 \pm 11 \mathrm{~kg}$ per $\mathrm{km}$ net. Bănaru et al. (2010) computed that the mean $\mathrm{CPUE}_{N}$ (fish No. per km of net) for albacore as a by-catch species was 0.084 specimen from the NW Mediterranean tuna driftnet fishery, collected seasonally between March and October in the 2000-2003 fishing seasons. This comparatively low CPUE for albacore in the NW Mediterranean implies a concern with its untargeted fish (i.e., Atlantic bluefin tuna was the target fish in the NW Mediterranean).

A total of 12 fish species were recorded as non-target catch. Moreover, a total of seven striped dolphin, Stenella coeruleoalba, became entangled in the driftnet off Fethiye in 2010, but five of them were released alive, while two of them died. However, other marine mammals were not observed during the sampling period. Fishermen claim that even (if only) a few dolphins and sea turtles occasionally become tangled in the net, they could be released safely. According to them, any dolphin and sea turtle casualties are due to chance and they have never seen any whale and sea birds entangled in the nets. The study of Öztürk et al. (2001) supports this statement as they showed that the only 19 dolphins-including S. coeruleoalba (13), Tursiops truncatus (4), and Grampus griseus (2) - in the Aegean Sea were reported from the swordfish driftnet fishery during May and June 1999 and 2000. Fishermen in the Fethiye region reported 23 entangled dolphins, of which 18 died, in 2002 season (Akyol et al. 2005). Cornax and Pardo (2009) stated that globally gillnets kill 300000 cetaceans each year around the world, most of them caught by driftnets, but we need to be aware that the above-mentioned paper is not a scientific pear-reviewer publication, but a popular science one sponsored by a nature conservation association. In the north-east Atlantic, French scientists conducted an observer programme in 1992 and 1993 to assess the ecological risk associated with the French use of $5 \mathrm{~km}$ nets, and this study produced an estimated bycatch in the

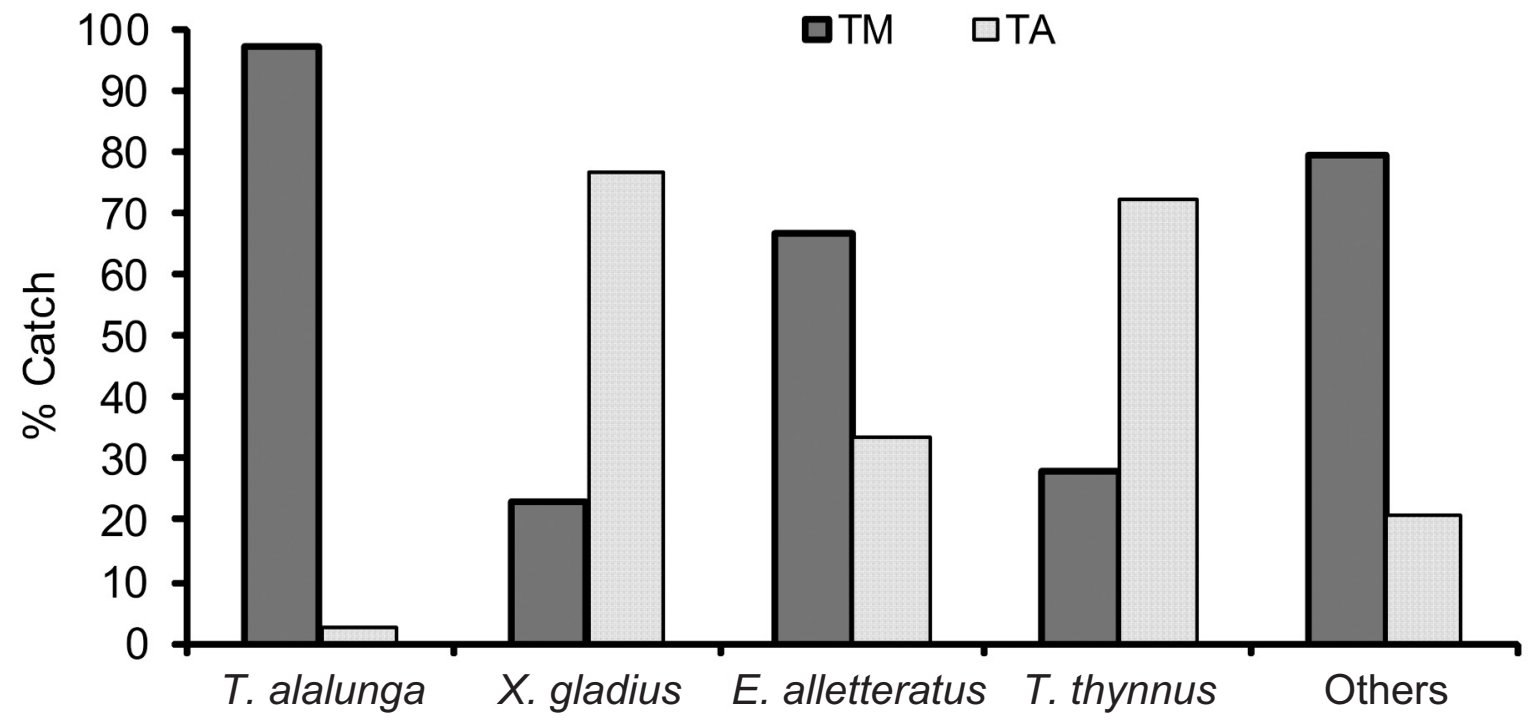

Fig. 2. Percentages of biomass for both target and non-target fishes in the two main fishing areas (TM, Turkish Mediterranean coast; TA, Turkish Aegean coast) 
French tuna driftnet fishery of 1700 cetaceans per year, including 1200 striped dolphins and 400 common dolphins (Ross and Isaac 2004). Karakulak et al. (2007) listed five fish species (T. thynnus, $X$. gladius, E. alletteratus, A. rochei, and Coryphaena hippurus L.) as non-target catch from Gulf of Antalya. The non-target catch in this study includes them. Rogan and Mackey (2007) determined that a total of 4366 blue sharks, Prionace glauca (L.); 1540 Atlantic pomfrets, Brama brama (Bonnaterre, 1788); 204 ocean sunfish, Mola mola (L.); 253 cetaceans (predominantly, Delphinus delphis and $S$. coeruleoalba followed by Globicephala melas, T. truncatus, Balaenoptera acutorostrata, Physeter macrocephalus, G. griseus, and Lagenorhynchus acutus); 4 seabird species; and 6 individuals of turtles were observed as the non-target catch in the Irish albacore tuna fishery in the NE Atlantic in two years, 1996 and 1998. Bănaru et al. (2010) reported that 22 nontarget catches from French driftnet fishery targeting primarily bluefin tuna in the north-western Mediterranean Sea between 2000 and 2003. The albacore ranked fifth with $1.5 \%$ as a by-catch species in the list. However, both bycatch lists (Rogan and Mackey 2007, Bănaru et al. 2010) contain many of cetaceans, sharks, and turtles, whereas most of them were absent (except $S$. coeruleoalba, Isurus oxyrinchus, Alopias vulpinus, and Caretta caretta) in our study. It seems clear that the by-catch species diversity and ratios are declined towards to the eastern Mediterranean.

In conclusion, the traditional Turkish pelagic driftnet fishery which dates back to the early 1900s (Deveciyan 1926) it is true name as a Turkish author was stopped in July 2011 by the Turkish fisheries authority in order to comply with the international ban. The fisheries authority strongly encourages the transition to the using pelagic longline as recommended by ICCAT and should be supplied the technical support to the fishermen.

\section{ACKNOWLEDGEMENTS}

This study was funded by Turkish Scientific and Technological Research Council (TUBITAK Project No. 108O210). Also, the authors thank the chair and members of the "Association of the Fishing for Swordfish and Albacore" for their help during the interviews and for giving us the opportunity to work freely onboard. We also thank two anonymous reviewers for their insightful comments which led to a much improved manuscript and Prof. Dr. Francis Juanes from the Fisheries Department of Biology, University of Victoria, Canada for improving the language of the text.

\section{REFERENCES}

Akyol O., Ceyhan T. 2011. Turkish swordfish fishery. Collective Volume of Scientific Papers ICCAT 66 (4): 1471-1479.

Akyol O., Ceyhan T. 2012. Moon phase's influence on CPUE of Turkish albacore gillnet fishery. Collective Volume of Scientific Papers ICCAT 67: (in press).

Akyol O., Erdem M., Ünal V., Ceyhan T. 2005. Investigations on drift-net fishery for swordfish (Xiphias gladius L.) in the Aegean Sea. Turkish Journal of Veterinary and Animal Sciences 29 (6): 1225-1231.
Anonymous 1995. STECF Subgroup on driftnet fisheries for tuna and tuna-like species. Commission of the European Communities, 1-3 Feb. 1995, Brussels, SEC(95) 549, Pp. 1-31.

Anonymous 2006. Denizlerde ve İçsularda Ticari Amaçlı Su Ürünleri Avcılığını Düzenleyen 2006-2008 Av Dönemine Ait 37/1 Numaralı Sirküler. [Turkish Fishery Regulation Circular (37/1) for Marine and Inland Commercial Fisheries in Fishing Season 2006-2008.] T.C. TKB-KKGM, R.G. Say1: 26269 Ankara. [In Turkish.]

Anonymous 2011. FishStatJ: Universal software for fishery statistical time series. FAO, Statistics and Information Service.

Bănaru D., Dekeyser I., Imbert G., Laubier L. 2010. Non-target and released alive by-catch distributions observed during French driftnet fishery in the northwestern Mediterranean Sea (2000-2003 database). Journal of Oceanography, Research and Data, 3 (3): 33-45.

Bartlett M.S. 1937a. Properties of sufficiency and statistical tests. Proceedings of the Royal Society of London, Series A 160 (901): 268-282.

Bartlett M.S. 1937b. Some examples of statistical methods of research in agriculture and applied biology. Supplement to the Journal of the Royal Statistical Society 4 (2): 137-183.

Ceyhan T., Akyol O., Karakulak F.S. 2011. Albacore fishery in Turkey. Collective Volume of Scientific Papers ICCAT 66 (5): 1867-1871.

Cornax M.J., Pardo E. 2009. A drift! Swordfish and driftnets in the Mediterranean Sea. Oceana-MarViva Mediterranean Sea Project 2008.

De Metrio G., Megalafonou P. 1988. Catch, size distribution, growth and sex ratio of swordfish (Xiphias gladius L.) in the Gulf of Taranto. FAO Fisheries Reports No. 394.

Deveciyan K. 1926. Türkiye'de Balık ve Balıkçlık. [Fish and Fisheries in Turkey.] Çeviri: Erol Üyepazarc1, Aras Yayıncılık, 2. Baskı, Nisan 2006, Istanbul. [In Turkish.]

Golani D., Öztürk B., Başusta N. 2006. Fishes of the eastern Mediterranean. Turkish Marine Research Foundation, Istanbul, Turkey, Publication No. 24.

Karakulak F.S., Bilgin B., Gökoglu M. 2007. Albacore (Thunnus alalunga Bonnaterre, 1788) fishery in Antalya Bay (Levantine Basin). Rapports de la Commission Intérnationale de la Mer Méditerranée 38: 512.

Öztürk B., Öztürk A.A., Dede A. 2001. Dolphin bycatch in the swordfish driftnet fishery in the Aegean Sea. Rapports de la Commission Intérnationale de la Mer Méditerranée 36: 308.

Rogan E., Mackey M. 2007. Megafauna bycatch in drift nets for albacore tuna (Thunnus alalunga) in the NE Atlantic. Fisheries Research 86 (1): 6-14. DOI: $10.1016 /$ j.fishres.2007.02.013

Ross A., Isaac S. 2004. The net effect? A review of cetacean bycatch in pelagic trawls and other fisheries in the north-east Atlantic. A WDCS report for Greenpeace. Whale and Dolphin Conservation Society

Zar J.H. 1999. Biostatistical analysis. 4th edn. Prentice-Hall, Upper Saddle River, NJ, USA.

Received: 29 July 2011

Accepted: 25 May 2012

Published electronically: 30 June 2012 